УДК 338. 47: 629. 44

ФОРМУВАННЯ МЕХАНІЗМУ УПРАВЛІННЯ ЕКОНОМІЧНОЮ ДІЯЛЬНІСТЮ ВАГОННОГО ГОСПОДАРСТВА

Д-р екон. наук В.В. Дикань, магістрант Д.С. Тимофєєв

ФОРМИРОВАНИЕ МЕХАНИЗМА УПРАВЛЕНИЯ ЭКОНОМИЧЕСКОЙ ДЕЯТЕЛЬНОСТЬЮ ВАГОННОГО ХОЗЯЙСТВА

Д-р екон. наук В.В. Дикань, магистрант Д.С. Тимофеев

\title{
FORMULATING MECHANISM OF MANAGEMENT OF ECONOMICAL ACTIVITIES OF THE ROLLING STOCKS
}

Doctor of economic sciences V.V. Dikan, master student D.S. Timofeev

Сформовано комплексний підхід до формування механізму управління економічною діяльністю вагонного господарства. Виявлено умови та фактори, які впливають на формування об'єктів управління економічною діяльністю залізничного транспорту. Встановлено, щзо об'єктами управління виступають організаційно відокремлені ланщюги вагонного господарства, а також структурні ланџюги системи управління і функиії, які мають свій механізм управління.

Ключові слова: механізм управління, економічна діяльність залізничного транспорту, принципи управління.

Сформирован комплексный подход к формированию механизма управления экономической деятельностью вагонного хозяйства. Выявлено условия и факторы, которые влияют на формирование объектов управления экономической деятельностью железнодорожного транспорта. Установлено, что в качестве объектов управления выступают организационно обособленные звенья 
вагонного хозяйства, а также структурные звенья системы управления и функции, которые имеют свой механизм управления.

Ключевые слова: механизм управления, экономическая деятельность железнодорожного транспорта, принципы управления.

A complex approach is formulated to the forming a mechanism of management of economic activities of the rolling stocks. Condition and factors of objects of management of economic activity of railway transport were identified. It was found in the domain of facilities management, perform organizational and separate units of the rolling stock and structural parts of the control system and functions, which have their control mechanism.

Keywords: the control mechanism, economic of railway transport, principles of management.

\begin{abstract}
Постановка проблеми. Залізничний транспорт $\epsilon$ складовою частиною господарського комплексу країни, який забезпечує необхідні потреби в реалізації економічних і соціальних зв'язків між різними галузями і регіонами країни, а також за іiі межами. I саме тому рівень розвитку залізничного транспорту повинен відповідати, а у ряді випадків навіть випереджати рівень розвитку основних галузей народного господарства України. 3 розвитком ринкових відносин в Україні, відбуваються корінні зміни в суспільному житті, внаслідок чого виникає потреба в удосконаленні методів управління економічною діяльністю залізничного транспорту. Особлива увага при цьому повинна приділятися вагонному господарству як складній багатоцільовій соціально-економічній системі. Механізм управління вагонним господарством повинен забезпечувати чітку взаємодію всіх його підсистем і вирішення завдань, які стоять перед ним.
\end{abstract}

Аналіз останніх досліджень та публікацій. Дослідженню проблем удосконалення механізму управління вагонним господарством приділили увагу такі вчені-економісти, як Позднякова Л.О. [4], Терьошина Н.П. [5], Корнійчук М.П. [6], Дмитрієв В.А. [7] та інші. В своїх працях автори описують проблематику управління економічною діяльністю залізничного транспорту як в цілому, так і по окремих його господарствах.

Виділення невирішених проблем. В даний час процес ухвалення будь-якого управлінського рішення відбувається в умовах, коли в країні протягом останнього часу спостерігається стабільне зниження ВВП. Обсяги робіт на залізничному транспорті залежать від стабільного функціонування інших підприємств народного господарства i, як наслідок, зниження в країні ВВП - зниження обсягів перевезень на залізничному транспорті. Тому актуальним $є$ питання удосконалення механізму управління вагонним господарством для забезпечення утримання стабільної його економічної діяльності.

\section{Виклад основного матеріалу} дослідження. Актуальність проблеми полягає в тому, що роль та місце вагонного господарства це не тільки забезпечення залізниць справним вагонним парком, який задовольняє вимоги безпеки руху, а й безпосередня участь у виконанні якісних перевезень, зокрема збереження вантажів, що транспортуються. Тобто вагонне господарство повинно забезпечити економне використання вагонів шляхом якісного виконання ремонтів, ефективної роботи підприємств тощо. Для цього формується належна виробнича база, що включає до себе вагонні депо, пункти технічного обслуговування вагонів та інші підрозділи.

Вагонне господарство як соціальноекономічна система являє собою єдність систем, яка управляє і якою управляють, а також сукупність технічної, технологічної та організаційної систем. Іншими словами, будьякий орган (ланцюг) управління вагонним господарством може бути i об'єктом, i суб'єктом управління залежно від того, чи $є$ він джерелом або приймальником управляючих дій.

Під управлінням об'єктом будемо розуміти процес ціленаправленого регулювання його стану. Управління є особливою формою діяльності в процесі виробництва товарів або послуг, що зумовлено розділенням праці, його спеціалізацією і кооперацією.

Функції виробничо-технічного відділу: технічне управління дільницями і відділами депо в частині впровадження нової техніки, механізації i автоматизації робіт, наукової 
організації праці; аналіз виробничогосподарської діяльності депо; розробка прогресивних технологічних процесів i організація їх впровадження; розробка графіків роботи обладнання депо $\mathrm{i}$ нагляд за його станом; розробка технічної документації на ремонт будівель, проектів та кошторисів на виконання капіталовкладень; розгляд та впровадження раціоналізаторських винаходів; організація навчання робітників правилам технічної експлуатації; технічна пропаганда та впровадження передового досвіду.

Диспетчерський апарат депо виконує оперативний контроль за виконанням змінних та добових завдань 3 ремонту вагонів, ремонту та виготовленню запасних частин, ремонту обладнання, постачання дільниць і відділень матеріалами та запасними частинами.

В механізмі управління вагонним господарством повинні бути враховані мотиви, які заохочують людей до діяльності, впровадження досягнень науки $\mathrm{i}$ техніки в виробництво, підвищення організованості праці, його ефективності та продуктивності.

Вагонне господарство як складна багатоцільова соціально-економічна система потребує, щоб механізм управління забезпечив чітку взаємодію всіх його підсистем i вирішення завдань, які стоять перед ним. 3 цих позицій у механізмі управління вагонним господарством виділяють соціальноекономічний та організаційний механізми.

Сутність соціально-економічного механізму полягає в очевидній для всіх залежності між результатами праці колективу, кожного робітника і прибутку підприємства, заробітної плати. Вказані залежності повинні бути такими, щоб виконувати функцію мотивації до творчого відношення до праці кожного робітника та керівника. Наявність існуючих інформаційних технологій, в тому числі й Інтернету, дозволяє реалізовувати на практиці таке поняття соціально-економічного механізму управління на ремонтних підприємствах, i в цілому у вагонному господарстві.

Економічний механізм управління ремонтними підприємствами може розглядатися як в масштабі управління виробничої дільниці або депо, так і в масштабі управління вагонного господарства більш високого рівня.
Актуальність розробки і реалізації соціально-економічних механізмів управління у вагонному господарстві значно зростає у зв'язку 3 реформуванням транспорту, серед цілей якого важливе місце займає настанова на створення конкурентного середовища в сфері таких послуг, як ремонт i технічне обслуговування рухомого складу. Залізничний транспорт функціонує як розділене ціле. До його складу входять різні служби, заводи, проектно-конструкторські організації, наукові та навчальні заклади. Всі вони виконують окремі функції, які наділені відповідними правами i відповідальністю. Ці елементи транспортної системи взаємопов'язані за допомогою встановлення чіткого порядку i форми взаємодіючих складових частин. Сказане відноситься і до будь-якої складної підсистеми транспортної системи, яка виконує автономну функцію. Завданнями 3 розділення єдиної, скажімо, системи забезпечення безпеки руху на складові частини, 3 розподілення між ними функцій, прав і відповідальності, із встановлення правил їх взаємодії виконує організаційний механізм управління безпеки руху. Розділення єдиної галузевої системи забезпечення безпеки руху реалізовано за ознакою приналежності об'єктів до тих або інших служб: підсистеми забезпечення безпеки вагонів, локомотивів, шляхів, організації руху. В свою чергу, кожна із вказаних підсистем, підкоряючись логіці дослідження, підлягає розділенню на більш дрібні складові частини. Так, підсистему забезпечення безпеки вагонів при вирішенні ряду завдань вигідно розділити відповідно до основних функцій вагонного господарства: своєчасне виявлення шкідливих ушкоджень та відмов відповідальних елементів конструкції вагонів, технічне обслуговування i поточний ремонт вагонів на шляху їх прямування, ремонти вагонів великого обсягу (ДР і КР), підготовка вагонів до перевезень, розробка технічних умов на нові конструкції вагонів, їх замовлення, своєчасне списування зношених вагонів.

Важливо вказати умови та фактори, які впливають на формування об'єктів управління.

В межах невеликої групи (бригада, виробнича дільниця депо) об'єктом управління $\epsilon$ людина i його праця. В більш широких масштабах об'єктом управління виступають великі колективи людей, виділені в 
організаційні ланцюги вагонного господарства (колектив депо, вагонної служби залізниці).

В соціально-економічній системі один і той же ланцюг може бути i об'єктом, i суб'єктом управління залежно від того, є він джерелом чи приймальником управляючих дій.

Тому під формуванням об'єкта управління розуміють організаційне виділення ланцюгів виробництва і системи управління ними. Основним структуроутворюючим ланцюгом вагонного господарства $\epsilon$ вагонне депо, яке виступає точкою відліку рівнів як в масштабі всього вагонного господарства, так і в масштабі депо. Саме депо $\epsilon$ основою формування об'єктів управління вагонного господарства різних масштабів: галузі, залізниці, відділення залізниці, відділку.

Виділення об'єктів управління здійснюється за функціями і трудомісткістю їх реалізації. Як сказано вище, об'єктами управління виступають організаційно відокремлені ланцюги вагонного господарства, а також структурні ланцюги системи управління і функції, які мають свій механізм управління. Відповідно до цього розділяють виробничі, структурні і функціональні об'єкти управління. Виділення об'єктів управління є основою організаційної побудови системи i механізму управління.

При формуванні об'єктів управління вагонним господарством необхідно враховувати економічні, організаційні, соціальні і техніко-технологічні фактори. Всі вони по-різному впливають на визначення масштабів і характеру об'єктів управління. Тому необхідний аналіз спільних дій цих факторів, а також їх ув'язування.

\begin{tabular}{lllr}
\multicolumn{2}{c}{ Економічні } & фактори & дозволяють \\
найбільш & повно & врахувати & потреби \\
економічних & законів & в управлінні & вагонним \\
господарством. & &
\end{tabular}

Процес управління підприємством починається 3 постановки завдань і планування. Функція планування полягає у визначенні цілі і завдань управління виробництвом, а також засобів досягнення цілей. Планування включає до себе прогнозування розвитку вагоноремонтного виробництва на основі, скажімо, математичного моделювання керованих об'єктів або використання методів експертних оцінок, встановлення термінів, темпів і пропорцій зростання або сповільнення виробництва. Це найбільш імовірна функція управління серед основних.

Координація направлена на підтримання потрібного співвідношення між різними елементами транспортної системи, забезпечення необхідної узгодженості дій робітників.

Функція стимулювання також $є$ формою прояву ціленаправленого впливу на робітників шляхом стимулювання до ефективної праці. Функція контролю полягає у систематичному нагляді за діяльністю робітників 3 метою виявлення відхилень від встановлених норм i правил, вимог до процесу функціонування ремонтних підприємств або органів управління.

В теорії управління розглядаються і так звані конкретні функції управління виробництвом. Якщо основні функції $\epsilon$ загальними для будь-яких процесів управління, то конкретні функції притаманні тим чи іншим конкретним елементам об'єкта управління, відображаючи їх специфіку. Питання полягає у виділенні вказаних об'єктів. Оскільки види діяльності достатньо великого ремонтного підприємства вагонного господарства багатогранні, то доцільно як об'єкт управління виділити тільки структурно відокремлені виробничо-господарські ланцюги.

Висновки 3 дослідження і перспективи, подальший розвиток у даному напрямку. Проведене дослідження механізму управління вагонним господарством залізниць України підтверджує необхідність удосконалення механізму управління економічною діяльністю вагонного господарства. Запропоновані заходи можуть бути запроваджені для покращення рівня системи забезпечення безпеки руху за допомогою підвищення ефективного функціонування підприємств вагонного господарства.

\section{Список використаних джерел}

1. Нацбанк раскрыл показатели обвала украинской экономики [Електронний ресурс]. - Режим доступу: http://pronedra.ru/globaleconomics/2015/01/17/ukraina-obval-ekonomiki/. 
2. Стабильное ухудшение [Электронный ресурс]. - Режим доступа: http://news.finance.ua/ru/news/-/358000/bezrabotitsa-dostigla-samogo-vysokogo-urovnya-za-vsyu-istoriyuukrainy-minsotspolitiki.

3. Спад промпроизводства на Украине в прошлом году ускорился до 17,9 \% [Электронный pecypc]. - Режим доступа: www.unian.net.

4. Позднякова, Л.О. Економіка залізничного транспорту [Текст] / Л.О. Позднякова, О.Г. Дейнека [та ін.]; за ред. Л.О. Позднякової. - Харків, 2010. - 251 с.

5. Терёшина, Н.П. Экономика железнодорожного транспорта [Текст] / Н.П. Терёшина, В.Г. Галабурда, М.Ф. Трихунков [и др.]; под ред. Н.П. Терёшиной, Б.М. Лапидуса, М.Ф. Трихункова. - М.: УМЦ ЖДТ, 2006. - 801 с.

6. Корнійчук, М.П. Технологія галузі і технічні засоби залізничного транспорту [Текст] / М.П. Корнійчук, Н.В. Липовець, Д.О.Шамрай. - К.: Дельта, 2008. - 500 с.

7. Дмитриев, В.А. Экономика железнодорожного транспорта [Текст] / В.А. Дмитриев, А.И. Журавель, А.Д. Шишков; под ред. В.А. Дмитриева. - М.: Транспорт, 1996. - 328 с.

8. Белов, И.В. Экономика железнодорожного транспорта [Текст] / И.В. Белов, Н.П. Терешина, В.Г. Галабурда [и др.], под ред. Н.П. Терешиной, Б.М. Лапидуса, М.Ф. Трихункова. - М.: УМК МПС России, 2001. -600 с.

9. Савицкая, Г.В. Анализ хозяйственной деятельности предприятия [Текст] / Г.В. Савицкая. Минск: ООО «Новое знание», 2002. - 704 с.

10. Галабурда, В.Г. Единая транспортная система [Текст] / В.Г. Галабурда. - М.: Транспорт, 1996. -295 c.

11. Белов, И.В. Экономика железнодорожного траснпорта [Текст] / И.В. Белов, В.Г. Галабурда, В.Ф. Данилин; под ред. И.В. Белова. - М.: Транспорт, 1989. - 351 с.

Дикань Олена Володимирівна, доктор екон. наук, професор, кафедра менеджменту i адміністрування, Український державний університет залізничного транспорту. Тел.: (057) 730-10-47. E-mail: gllo2012@mail.ua.

Тимофєєв Дмитро Сергійович, магістрант кафедри менеджменту і адміністрування Українського державного університету залізничного транспорту. E-mail: timofeev_d@mail.ua.

Dikan Olena, doctor of economic sciences, professor, of the management and administration of Ukrainian State University of Railway Transport. тел.: (057) 730-10-47. E-mail: gllo2012@mail.ua

Timofeev Dmitry, master student of the management and administration of Ukrainian State University of Railway Transport. E-mail: timofeev_d@mail.ua.

Наукова праця здана до друку 06.10.2015 р. 